\title{
XXVII CONGRESSO BRASILEIRO DE CIRURGIA: CIRURGIA E CONHECIMENTO NA ERA DA TECNOLOGIA
}

\section{BRAZILIAN CONGRESS OF SURGERY: SURGERY AND KNOWLEDGE IN TIMES OF TECNOLOGY}

\author{
Mário Ribeiro-TCBC \\ Presidente da Comissão Científica
}

\begin{abstract}
O Colégio Brasileiro de Cirurgiões foi fundado em 30 de julho de 1929, no Rio de Janeiro. Dentre os seus objetivos iniciais, já constava a formação e atualização científica do cirurgião. O primeiro Congresso Brasileiro de Cirurgia foi realizado em 1938, no Rio de Janeiro. Não havia, naquela época, regularidade dos intervalos entre os congressos brasileiros, sendo o segundo realizado um ano após o primeiro e, entre o quarto e o quinto congressos, passaram-se nove anos. O primeiro congresso fora do Rio de Janeiro (oitavo brasileiro) foi realizado em 1963 em São Paulo, ocasião em que o Colégio já tinha trinta e quatro anos de existência. De 1959 a 1973, foi realizado a cada dois anos e, a partir daí, a cada três anos até 1991, quando voltou a ser bianual. Excetuando-se os realizados no eixo Rio-São Paulo, tivemos um Congresso Brasileiro
\end{abstract} em Recife em 1997 e um em Porto Alegre em 2003.

Minas Gerais teve seu Capítulo do Colégio Brasileiro de Cirurgiões criado em 1944. É a terceira maior representação regional dos cirurgiões no Brasil, considerando-se o número total de membros, de titulares e de eméritos. Minas Gerais sempre esteve entre as maiores delegações presentes ao Congresso Brasileiro de Cirurgia.

Há muito tempo, os mineiros sonham com a oportunidade de sediar o evento. Dispomos de localização central neste "país-continente", rede hoteleira ampla e competitiva em relação à qualidade e aos preços, e centro de convenções de fácil e rápido acesso aos congressistas. As montanhas de Minas, suas cidades históricas, sua cultura barroca, a culinária ímpar e, principalmente a tradicional hospitalidade mineira, representam um atrativo adicional.

Os Congressos Brasileiros vêm mantendo significativo público presente, ainda que o acesso ao conhecimento tenha sido muito facilitado nos últimos anos. Provavelmente isto ocorre pela oportunidade dos cirurgiões de dedicarem aquele tempo à sua formação e atualização científicas, discu- tindo casos e situações complexas com colegas de maior experiência.

Sabemos da importância deste Congresso !

Extremamente honrados com a tarefa, estamos trabalhando arduamente, com uma equipe coesa e interessada, envolvendo membros de múltiplos estados brasileiros.

Nosso tema central, sem desvalorizar a moderna propedêutica e a terapêutica disponíveis, chama atenção para o fato de que o papel do conhecimento científico, a capacidade de análise e o discernimento do cirurgião ainda são primordiais nos resultados finais do tratamento cirúrgico.

Simultaneamente ao evento, será realizado o IX Congresso dos Fellows Latinoamericanos do Colégio Americano de Cirurgiões. As Comissões organizadoras e científicas dos dois congressos estão trabalhando em perfeita sintonia e encontramse confiantes na realização de um excepcional conclave científico.

A Comissão Científica estruturou a programação de forma bastante atual e abrangente, para recepcionar especialistas do Brasil inteiro e também da América Latina, promovendo uma reciclagem de alto nível. Contaremos com a participação de nomes expressivos da cirurgia mundial, além de numerosos ícones da cirurgia brasileira. Dos Estados Unidos virão doze especialistas e o Congresso ainda vai contar com palestrantes do Chile, Colômbia, França, Peru e Uruguai. Teremos três Cursos Pré-Congresso (Cirurgia Bariátrica, Trauma e Videocirurgia), três Workshops (Infecção em Cirurgia, Oncologia e Transplantes de Órgãos), três Simpósios de Especialidades (Cirurgia Torácica, Cirurgia Vascular e Coloproctologia), numerosas Conferências e Mesas Redondas, além de Consensos e Sessões intituladas "Comportamento em Situações Controversas".

Estamos otimistas em relação ao sucesso do XXVII Congresso Brasileiro de Cirurgia, para o qual reafirmamos nosso convite à sua participação. 